\title{
Microbial activity at the deep water sediment boundary layer in two highly productive systems in the Western Mediterranean: the Almeria-Oran front and the Malaga upwelling
}

\section{Activité microbienne à l'interface eau-sédiment dans deux écosystèmes productifs de Méditerranée occidentale : le front Alméria-Oran et l'upwelling de Malaga}

\author{
Armand Bianchi ${ }^{\mathrm{a}, *}$, Antoni Calafat ${ }^{\mathrm{b}}$, Rutger De Wit ${ }^{\mathrm{c}}$, Jean Garcin ${ }^{\mathrm{a}}$, Olivier Tholosan ${ }^{\mathrm{a}}$, \\ Isabel Cacho ${ }^{\mathrm{b}}$, Miquel Canals ${ }^{\mathrm{b}}$, Joan Fabrés ${ }^{\mathrm{b}}$, Hélène Grout ${ }^{\mathrm{b}}$, Pere Masqué ${ }^{\mathrm{d}}$, \\ Joan-Albert Sanchez-Cabeza ${ }^{\mathrm{d}}$, Richard Sempéré ${ }^{\mathrm{a}}$ \\ ${ }^{a}$ Microbiologie Marine, UMR 6117 CNRS - INSU and Université de la Méditerranée, COM, Campus de Luminy, Case 907, \\ 13288 Marseille, cedex 9, France \\ ${ }^{\mathrm{b}}$ GRC Geociències Marines, Department Estratigrafia i Paleontologia, Universitat de Barcelona, 08028, Barcelona, Spain \\ ${ }^{\mathrm{C}}$ Laboratoire d'Océanographie Biologique, UMR 5805, CNRS and Université Bordeaux 1, 33120, Arcachon, France \\ ${ }^{\mathrm{d}}$ Centre d'Estudis Ambiantals, Departament de Física, Universitat Autònoma de Barcelona, 08193, Barcelona, Spain
}

Received 24 June 2002; received in revised form 30 September 2002; accepted 1 October 2002

\begin{abstract}
Microbiological and biogeochemical studies were carried out in sediments and near bottom waters in the upwelling area off the Malaga coast and in the Almeria-Oran frontal zone. In these nutrient-rich conditions, metabolic activity is potentially limited by oxygen availability through the sediment depth. In the surficial sediments of the frontal zone, however, oxygen penetrated to a depth of $4 \mathrm{~cm}$, allowing oxic mineralisation processes to occur throughout the layer. In the surficial sediments of the upwelling area, oxygen penetration was limited to the top $2.5 \mathrm{~cm}$, leading to anoxic conditions. Glutamate respiration and global oxygen uptake rates were clearly higher than in the frontal zone. In the superficial sediments of the frontal zone, bacteria were less abundant and showed the lowest potential rate for mineralisation processes, but the highest rate for proteolysis. This discrepancy is probably due to differences in the quality of organic inputs into the two areas, with labile organic compounds reaching the sea bottom in the shallower upwelling zone. Such inputs enhance the mineralisation of low molecular weight monomers, whilst inhibiting the polymer hydrolysis processes. Conversely, in the deeper frontal zone, labile monomers become exhausted, decreasing the mineralisation rates. Concomitantly, bacteria have to develop ectoenzymatic activities in order to extract their carbon and energy from the available semi-labile polymers. Consequently, the theoretical relationship between the mineralisation and hydrolysis processes are tightly coupled in the upwelling area, and uncoupled in the frontal zone.
\end{abstract}

(C) 2002 Ifremer/CNRS/IRD/Éditions scientifiques et médicales Elsevier SAS. All rights reserved.

\section{Résumé}

La distribution de facteurs biogéochimiques et de divers processus microbiens a été étudiée dans les eaux proches du fond et les sédiments superficiels dans la zone de l'upwelling de Malaga et au niveau du front Almeria-Oran. Dans ces conditions relativement eutrophes, les activités métaboliques sont limitées par la disponibilité de l'oxygène moléculaire dans l'épaisseur sédimentaire. Toutefois, dans les sédiments de la zone frontale l'oxygène pénètre jusqu'à $4 \mathrm{~cm}$ de profondeur, permettant le développement de processus oxiques à travers cette couche. Par contre, dans la zone d'upwelling, où la vitesse potentielle de respiration du glutamate et la consommation globale d'oxygène sont nettement supérieures à celles de la zone frontale, la pénétration de l'oxygène est limitée à $2,5 \mathrm{~cm}$, conduisant à l'anoxie

\footnotetext{
* Corresponding author.

E-mail address: a-bianchi@com.univ-mrs.fr (A. Bianchi).
} 
à partir de ce niveau. Dans les sédiments superficiels de la zone frontale, les bactéries sont moins abondantes, et moins actives dans le processus de respiration du glutamate, que leurs homologues de la zone d'upwelling. Par contre, leur potentiel d'hydrolyse des polypeptides est plus développé. Cette divergence est probablement due à la différence de qualité des apports en matières organiques dans les deux zones. Par rapport à la zone frontale, dans la zone d'upwelling moins profonde les apports au domaine benthique incluent une fraction plus labile. Ces apports en matériel labile dopent les processus de minéralisation des monomères, alors que par un effet de retro-inhibition ils ralentissent l'hydrolyse des polymères. À l'opposé, dans la zone frontale plus profonde, le matériel atteignant le domaine benthique a été épuisé de sa fraction labile, ce qui provoque un ralentissement des vitesses de minéralisation des monomères. Simultanément, les bactéries doivent développer des activités ectoenzymatiques pour pouvoir extraire des polymères semi-réfractaires disponibles le carbone nécessaire à leur métabolisme. En conséquence, les relations entre les processus d'hydrolyse et de minéralisation sont couplés dans la zone d'upwelling et découplés dans la zone frontale.

(C) 2002 Ifremer/CNRS/IRD/Éditions scientifiques et médicales Elsevier SAS. Tous droits réservés.

Keywords: Bacteria; Mineralisation rate; Sediments; Deep-sea; Western Mediterranean

Mots clés: Taux de minéralisation; Sédiments; Eaux profondes; Méditerranée occidentale

\section{Introduction}

The organic matter bulk in the ocean is a complex mixture including dissolved and particulate material, comprising both low and high-molecular weight compounds. Microbial communities are known to use these materials throughout the water column, from the productive surface layers down to the near bottom waters (Poremba, 1994; Turley and Mackie, 1994; Hoppe and Ullrich, 1999). Thus, the quantity and quality of nutrients reaching the sea floor are dependent on the residence time in the water column.

Dissolved organic material (DOM) constitutes the bulk of the total organic matter reservoir in the water column. However, rapidly sinking, large particles or aggregates pass through the pelagic biological filter, and constitute the main source of energy-rich material onto the sea floor (Alldredge and Silver, 1988). Frontal zones are known to induce the sinking of particulate material towards the deeper layers (Prieur et al., 1993). As such, most of the organic bulk in these benthic areas is composed of high-molecular weight compounds (Boetius and Lochte, 1994), so that the benthic zone is enriched with surface nutrients, which usually do not reach the sea bottom.

We studied microbial activity in two neighbouring benthic areas in the Alboran Sea (Western Mediterranean Sea), characterised by different hydrological conditions. The first was in the frontal zone of Almeria-Oran (Prieur et al., 1993), the second in the upwelling area of Malaga (Minas et al., 1991). The main objective of this work was to study how benthic microbial communities adapt their metabolic activities to the input of organic nutrients that are carried down to the deep-sea. The comparison is made in two areas of high-productivity, which are submitted to different hydrological conditions.

\section{Materials and methods}

\subsection{Sampling areas}

The Alboran Sea is the western most basin of the Mediterranean Sea. It is sub-divided into two sub-basins (Eastern and Western) by the Alboran ridge (geographically separated by Cape Tres Forcas and the Alboran Island). The hydrological surface dynamics are controlled by the jet inflow of Atlantic Water that follows a wave-like path to the east, feeding two anticyclonic gyres centred in the subbasins, the Western gyre and the Eastern gyre (GarcíaLafuente et al., 1998). High-productivity systems are particularly active in the Malaga zone, a coastal upwelling along the northern edge of the Western gyre, and through the Almeria-Oran axis, a geostrophic frontal system developed in the eastern side of the Eastern gyre.

During Leg 1 of Mater/Hesp/April 1998 cruise on board RV 'Hesperides', (20-30 April 1998), microbiological and biogeochemical studies were carried out in these highly productive areas of the Alboran Sea (Fig. 1). The upwelling zone off the Malaga coast (UPW) is located at the northern margin of the eastern sub-basin and features a gentle slope from 650 to $1300 \mathrm{~m}$ (Minas et al., 1991). The Almeria-Oran front in the eastern part of the oriental sub-basin is an abyssal plain reaching depths of $2382 \mathrm{~m}$ and is connected to the Algerian Basin (Prieur et al., 1993).

Sediments and overlying waters (approximately 10-20 cm) were sampled at eight stations (Table 1) with a multitube corer. For each core, the near bottom water (NBW) was carefully and aseptically collected by siphoning into a polycarbonate bottle. The core was then aseptically sliced (at 0-2, 2-4 and 4-6 cm depths). Each sediment slice was re-suspended into its own NBW (previously $0.2 \mu \mathrm{m}$ filtered) to provide a $1 / 4$ dilution $(\mathrm{v} / \mathrm{v})$.

\subsection{Microbial abundance}

In near bottom waters and sediment slurries, bacteria were stained with Dapi (4'6-diamidino-2-phenylindole) and then counted using an epifluorescence microscope (Porter and Feig, 1980).

\subsection{Extraellular potential proteolytic activity}

Potential protease activity was measured in the sediment slurries using the fluorogenic substrate analogue Leu-MCA (1-leucine-7-amino-4-methylcoumarin) (Sigma Chemical 


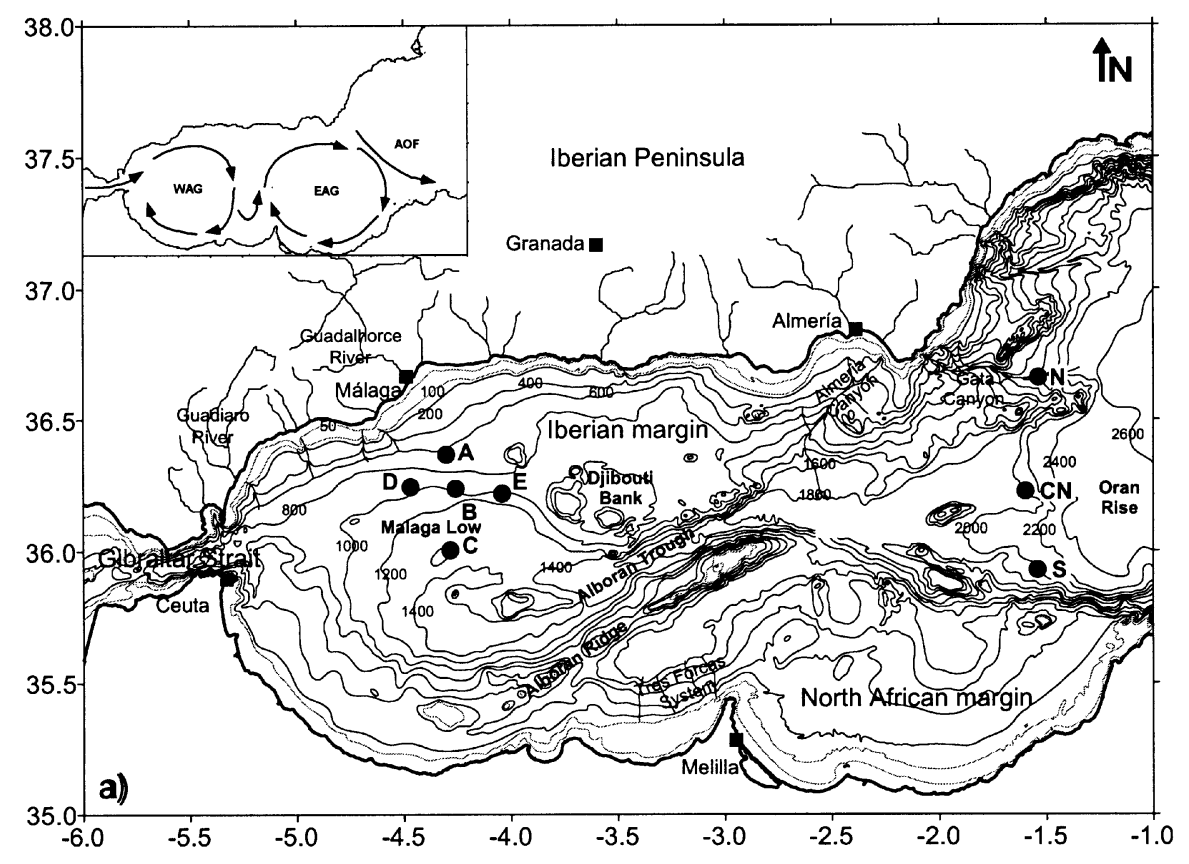

Fig. 1. Map of the Alboran Sea showing station positions (A, B, C, D, E, N, CN and S). The inset on the upper left corner outlines the theoretical surface circulation in Alboran Sea (WAG: Western Alboran Gyre; EAG: Eastern Alboran Gyre; AOF: Almeria-Oran Front).

Co.) (Hoppe, 1983). This compound competes well with easily degradable natural peptides (Chrost, 1991).

\subsubsection{Sediment samples}

Sediment slurries $(1 / 4, \mathrm{v} / \mathrm{v})$ were processed as described in (Tholosan and Bianchi, 1998), using 12 substrate final concentrations $(25,50100,150,200,250,300,400,500$, $1000,1500$ and $2000 \mu \mathrm{M})$. Enzyme assays were run over time course experiments of 2, 4, 6 and $12 \mathrm{~h}$. Fluorescence was determined using a Kontron SFM 25 spectrofluorometer (emission and excitation wavelengths of 455 and $365 \mathrm{~nm}$, respectively). A calibration curve was achieved for each sediment slice using a range of MCA concentrations of between 10 and $60 \mu \mathrm{M}$.

\subsubsection{Near bottom water samples}

Eight different concentrations (10, 20, 50, 100, 200, 300, 400 and $500 \mathrm{nM}$ ) were used to determine $V_{\mathrm{m}}$. Time course experiments lasted $8 \mathrm{~h}$. For each incubation period $(0,2,4$, and $8 \mathrm{~h}$ ), subsamples were poured into a quartz cuvette for the measurement of fluorescence. A standard curve was drawn from a range of MCA concentrations.

\subsection{Potential heterotrophic activity}

\subsubsection{Near bottom water samples}

A solution of $1-\left(\mathrm{U}^{-14} \mathrm{C}\right)$-glutamate, specific activity 9.77 $\mathrm{GBq} \mathrm{mmol}^{-1}$ (Amersham Corp.), was added to give a final concentration of $10 \mathrm{nM}$. Time course experiments were run over $3 \mathrm{~h}$, in the dark at in situ temperature $\left(13 \pm 1^{\circ} \mathrm{C}\right)$. Samples were processed as described in (Tholosan and Bianchi, 1998).

\subsubsection{Sediment samples}

Sediment slurry $(1 / 4, \mathrm{v} / \mathrm{v})$ was distributed in $15 \mathrm{ml}$ sterile penicillin flasks (200 $\mu \mathrm{l}$ per flask). A solution of $1-\left(\mathrm{U}^{-14} \mathrm{C}\right)$ glutamate, specific activity $9.77 \mathrm{GBq} \mathrm{mmol}^{-1}$ (Amersham Corp.), was added to give a final concentration of $1 \mu \mathrm{M}$. The labelled subsamples were incubated at $13{ }^{\circ} \mathrm{C}$ for 60,180 and $360 \mathrm{~min}$ and were processed as previously described (Tholosan and Bianchi, 1998).

Table 1

Localisation and depth of sampling stations for benthic microbiology studies during Mater/Hesp/Apr98 cruise in the Alboran Sea. F: frontal area; $\mathrm{U}$ : upwelling area

\begin{tabular}{lllccc}
\hline Date & Area & Station & Depth $(\mathrm{m})$ & N latitude & W longitude \\
\hline $21 / 04 / 98$ & $\mathrm{~F}$ & $\mathrm{~S}$ & 2018 & $35^{\circ} 55.13^{\prime}$ & $01^{\circ} 07.72^{\prime}$ \\
$22 / 04 / 98$ & $\mathrm{~F}$ & $\mathrm{~N}$ & 2382 & $36^{\circ} 55.65^{\prime}$ & $01^{\circ} 06.70^{\prime}$ \\
$21 / 04 / 98$ & $\mathrm{C}$ & $\mathrm{CN}$ & 2095 & $36^{\circ} 12.38^{\prime}$ & $01^{\circ} 32.54^{\prime}$ \\
$23 / 04 / 98$ & $\mathrm{U}$ & $\mathrm{B}$ & 684 & $36^{\circ} 14.10^{\prime}$ & $04^{\circ} 13.55^{\prime}$ \\
$24 / 04 / 98$ & $\mathrm{U}$ & $\mathrm{A}$ & $36^{\circ} 23.63^{\prime}$ & $04^{\circ} 14.35^{\prime}$ \\
$25 / 04 / 98$ & $\mathrm{C}$ & $\mathrm{C}$ & $36^{\circ} 00.32^{\prime}$ & $04^{\circ} 17.03^{\prime}$ \\
$26 / 04 / 98$ & $\mathrm{U}$ & $\mathrm{D}$ & 936 & $36^{\circ} 14.31^{\prime}$ & $04^{\circ} 27.12^{\prime}$ \\
$28 / 04 / 98$ & $\mathrm{U}$ & $\mathrm{E}$ & 993 & $36^{\circ} 13.27^{\prime}$ & $04^{\circ} 01.38^{\prime}$ \\
\hline
\end{tabular}




\subsection{Particle flux}

Particle flux determinations were made using mooring arrays equipped with Technicap-PPS3. Sediment traps were deployed during July 1997 to May 1998. Four were placed south of Malaga over the continental slope (stations B, C, D and $\mathrm{E}$ ), and three following a line between Almeria and Oran (stations $\mathrm{N}, \mathrm{CN}$ and $\mathrm{S}$ ). All moorings were equipped with several sediment traps, deployed at 500,1000 and then $30 \mathrm{~m}$ above the sea floor.

The total dry mass was determined gravimetrically on 4-6 subsamples, following the removal of the largest organisms $(>1 \mathrm{~mm})$ and swimmers. Particle flux data presented are the mean values taken from the last measurement period, March-May 1998, and from the near bottom trap (30 $\mathrm{m}$ above the sea floor).

\subsection{Concentrations of organic carbon and nitrogen}

Discrete seawater samples were collected using a CTD rosette system equipped with 101 Niskin bottles fitted with steel closure springs. The $10 \mathrm{ml}$ samples were collected without filtration in duplicate into precombusted $\left(450{ }^{\circ} \mathrm{C}\right.$, for a minimum of $6 \mathrm{~h}$ ) glass vials, poisoned with $\mathrm{HgCl}_{2}$ $\left(10 \mathrm{mg} \mathrm{l}^{-1}\right)$, sealed with Teflon lined screw caps and stored in the dark. Total organic carbon (TOC) was measured using a Shimadzu TOC-5000 Total Carbon Analyser with quartz combustion column filled with $1.2 \% \mathrm{Pt}$ on silica.

Several aspects of our modified unit have been previously described (Dafner et al., 1999). Briefly, prior to analysis, samples were acidified ( $\mathrm{pH} 2$ ) with $85 \%$ phosphoric acid and sparged for 10 min with $\mathrm{CO}_{2}$-free pure air to remove inorganic carbon as $\mathrm{CO}_{2}$. Standardisation was carried out daily using potassium hydrogen phthalate (Kanto Chemical Company, Inc.) dissolved in Milli-Q water and prepared just before sample analyses. The instrument response factor measured as the slope of the standard addition $\left(r^{2}>0.999\right.$ for 10 runs) remained relatively constant $(5839 \pm 145)$ and reproducible throughout the analysis period. The instrument blank averaged $11 \pm 2 \mu \mathrm{M} \mathrm{C}$, and was subtracted from the measured values.

Analysis of particulate organic carbon and nitrogen from the sediments was determined using a Fisons NA1500 CHN Elemental Analyser, following the removal of carbonate using $1 \mathrm{M} \mathrm{HCl}$.

\subsection{Oxygen profiles}

Oxygen profiles were measured through the sediment layer, immediately after recovery, on cores that had been incubated in a water bath $\left(13 \pm 1{ }^{\circ} \mathrm{C}\right)$. The polarographic oxygen sensor was a simple cathode type, custom-made, mini-electrode, constructed in a $1 \mathrm{~mm}$ diameter hypodermic needle (De Wit et al., 1997). It was polarised at $-750 \mathrm{mV}$ with respect to the mini-reference electrode (Diamond Inc., USA). A two-point calibration was performed for each profile. (1) In the overlying water column (oxygen concentrations were measured independently on board, using
Winkler titrations and (2) the residual current at zero oxygen, measured in the anoxic layer of the core.

Two profiles were sequentially measured in each core. Usually, duplicates are similar indicating that oxygen profiles within a core are homogeneous and in a steady state, reflecting the in situ conditions at the sea floor. From each sampling station, two cores were studied, obtained from duplicate corers. The profiles obtained from these showed little variation. Therefore, the four oxygen profiles obtained from each sampling station were treated as four replicates.

The diffusive oxygen uptake rate $\left(J_{(0)}\right)$ describes the diffusive flux of oxygen across the water-sediment interface. Oxygen taken from the water column into the sediment is expressed per unit area, which corresponds to the total amount of oxygen consumed by the sediment per unit of time. The oxygen uptake rate $(R)$ corresponds to the amount of oxygen consumed by a known volume of sediment per unit of time and represents a volumetric rate with a depth distribution. $\left(J_{(0)}\right)$ and $(R)$ were calculated with Fick's diffusion laws applied to the sediment, using a parabolic curve-fitting approach, assuming steady-state conditions and zero-order kinetics (De Wit et al., 1997). One to three different depth layers with different kinetics were recognised, and the boundaries between these different layers were mathematically adjusted (boundary condition) to prevent discontinuities in the slope of the fitted curve.

\section{Results}

\subsection{Deep water characteristics}

The bottom and deep waters (below $600 \mathrm{~m}$ ) of the Alboran basin are referred to as the Western Mediterranean Deep Waters. This water is characterised by low temperatures $\left(12.7-12.8^{\circ} \mathrm{C}\right)$, and low salinity $(38.4-38.5)$ (Parrilla et al., 1986). They are oxygenated, showing a slight increase in oxygen concentration from 4.5 to $4.8 \mathrm{ml} \mathrm{l}^{-1}$ at 1000-2500 m (Packard et al., 1988).

In the water column of the upwelling area, concentrations of TOC (Table 2), including suspended particulate and the dissolved fraction, ranged from 40 to $60 \mu \mathrm{M} \mathrm{C}$. Concentrations in the Almeria-Oran front ranged from 45 to $74 \mu \mathrm{M} \mathrm{C}$, being consistent with previous observations (Grout et al., 2001; Sempéré et al., submitted). In both the frontal zone and the upwelling area, the highest TOC concentrations were observed in the surface waters $(79 \mu \mathrm{M} \mathrm{C}$ at $50 \mathrm{~m}$, and $78 \mu \mathrm{M}$ $\mathrm{C}$ at $5 \mathrm{~m}$, respectively). The profiles show a slight decrease in TOC concentration with depth (Table 2), the lowest concentrations (47-49 $\mu \mathrm{M} \mathrm{C}$ ) being observed in mesopelagic waters (500-643 m). TOC values (Table 2) within the top layer $(110 \mathrm{~m})$ were higher in the frontal zone $\left(6101 \mathrm{mmol} \mathrm{C} \mathrm{m}^{-2}\right)$ than in the upwelling area $\left(5597 \mathrm{mmol} \mathrm{C} \mathrm{m}^{-2}\right)$.

Semi-labile TOC concentrations were calculated as the difference in concentration above $110 \mathrm{~m}$ and below $500 \mathrm{~m}$ (averaged for the two study areas, assuming an equal distribution of the refractive TOC pool throughout the water 
Table 2

Total organic carbon (TOC) averaged concentrations (two casts sampled at two consecutive days) in the water column, and integrated distribution of TOC and semi-labile TOC through the $0-110 \mathrm{~m}$ thick water layer

\begin{tabular}{|c|c|c|}
\hline Depth (m) & $\begin{array}{l}\text { TOC ( } \mu \mathrm{M} \text { C) } \\
\text { Upwelling }\end{array}$ & Frontal \\
\hline 5 & 78 & 77 \\
\hline 30 & 64 & 76 \\
\hline 50 & 73 & 79 \\
\hline 80 & 64 & 71 \\
\hline 110 & 61 & 67 \\
\hline 500 & 59 & 49 \\
\hline 643 & 47 & 56 \\
\hline Integrated data $0-110 \mathrm{~m}$ & $\mathrm{~m} \mathrm{~mol} \mathrm{C} \mathrm{m}{ }^{-2}$ & $\mathrm{~m} \mathrm{~mol} \mathrm{C} \mathrm{m}^{-2}$ \\
\hline TOC & 5597 & 6101 \\
\hline TOC semi-labile \% & 31 & 40 \\
\hline
\end{tabular}

column). Interestingly, stocks of semi-labile TOC were higher in the frontal zone $\left(2449 \mathrm{mmol} \mathrm{C} \mathrm{m}^{-2}\right)$ than in the upwelling area we studied $\left(1759 \mathrm{mmol} \mathrm{C} \mathrm{m}^{-2}\right)$. An accumulation of semi-labile TOC indicates significant differences in the balance between the production of dissolved organic carbon (DOC) by autotrophs and higher heterotrophs, and the assimilation of DOC by heterotrophic bacteria.

\subsection{Sediment characteristics}

Particle flux data (April-May 1998) were obtained from the upwelling area using sediment traps deployed $30 \mathrm{~m}$ above the bottom, mean values were 1188 and $1101 \mathrm{mg} \mathrm{m}^{-2} \mathrm{~d}^{-1}$ at stations $\mathrm{C}$ and $\mathrm{B}$, respectively. In the frontal zone, particle fluxes were much lower, 663 and $306 \mathrm{mg} \mathrm{m}^{2} \mathrm{~d}^{-1}$ at stations $\mathrm{S}$ and $\mathrm{N}$, respectively.

All sediments exhibited a brownish oxic surface layer with high Eh values. The depth of the surface oxidised layer ranged from $25 \mathrm{~mm}$ at Station $\mathrm{S}$, to $100 \mathrm{~mm}$ at station $\mathrm{N}$. The surface sediments consisted of sand-silt, the percentage of silt-sized particles being about $80 \%$. In the upwelling area, the average percentage of organic carbon, found in the $6 \mathrm{~cm}$ upper layer, gradually decreased with water column depth; $1.4 \%$, at station A $(656 \mathrm{~m})$, nearly $1.0 \%$ at stations B, $\mathrm{D}$ and $\mathrm{E}$ (around $950 \mathrm{~m})$, and $0.7 \%$ at station $\mathrm{C}(1321 \mathrm{~m})$. At the deeper frontal zone, the corresponding percentages were similar, i.e. $0.9 \%$ at station $\mathrm{N}(2382 \mathrm{~m})$, and $1.1 \%$ at stations $\mathrm{S}$ and CN (2018 and $2095 \mathrm{~m}$, respectively).

\subsection{Oxygen profiles}

The diffusive oxygen uptake rates ranged from 1.30 to $2.38 \mathrm{mmol} \mathrm{O}_{2} \mathrm{~m}^{-2} \mathrm{~d}^{-1}$ (Table 3). These rates were usually slightly higher along the Almeria-Oran frontal zone than in the Malaga upwelling area, with the exception of station D where the highest rate was observed. Concomitantly, the diffusive oxygen penetration depths ranged from 3.8 to $4.6 \mathrm{~cm}$ along the Almeria-Oran frontal zone but were limited to a depth of $2.2-2.9 \mathrm{~cm}$ in the Malaga upwelling area (Fig. 2, Table 3).

In the topmost centimetre, the oxygen uptake rates were higher along the Almeria-Oran frontal zone than in the
Table 3

Oxygen penetration depth $(\mathrm{cm})$ and diffusive oxygen uptake rate $\left(\mathrm{mmol} \mathrm{m} \mathrm{m}^{-2} \mathrm{~d}^{-1}\right)$ estimated from benthic oxygen profiles in sediment cores sampled in replicate (mean $\pm \mathrm{SEM}, n=4)$. F: frontal area; $\mathrm{U}$ : upwelling area

\begin{tabular}{llll}
\hline St. & Area & $\begin{array}{l}\text { Oxygen penetration depth } \\
(\mathrm{cm})\end{array}$ & $\begin{array}{l}\text { Diffusive oxygen uptake rates } \\
\left(\mathrm{mmol} \mathrm{O}_{2} \mathrm{~m}^{-2} \mathrm{~d}^{-1}\right)\end{array}$ \\
\hline $\mathrm{S}$ & $\mathrm{F}$ & 3.8 & 1.68 \\
$\mathrm{~N}$ & $\mathrm{~F}$ & $4.6 \pm 0.1$ & $1.90 \pm 0.04$ \\
$\mathrm{CN}$ & $\mathrm{F}$ & 4.1 & 1.94 \\
$\mathrm{~B}$ & $\mathrm{U}$ & $2.6 \pm 0.1$ & $1.30 \pm 0.23$ \\
$\mathrm{~A}$ & $\mathrm{U}$ & $2.2 \pm 0.1$ & $1.53 \pm 0.11$ \\
$\mathrm{C}$ & $\mathrm{U}$ & $2.8 \pm 0.2$ & $1.38 \pm 0.15$ \\
$\mathrm{D}$ & $\mathrm{U}$ & $2.9 \pm 0.1$ & $2.38 \pm 0.43$ \\
E & $\mathrm{U}$ & $2.9 \pm 0.1$ & $1.34 \pm 0.20$
\end{tabular}

Oxygen concentration $(\mu \mathrm{M})$
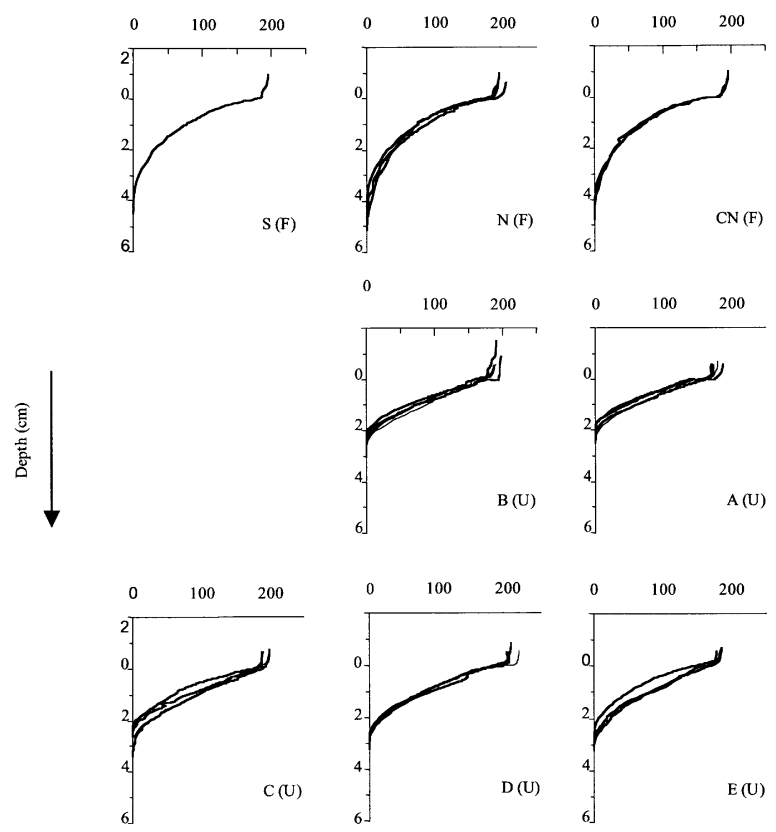

Fig. 2. Depth profiles of oxygen concentrations in sediment cores collected in the Alboran Sea. Stations are listed in Table 1; (F): frontal area; (U): upwelling area.

upwelling area, except at station D where this rate was maximal (Fig. 3). In the frontal zone, these rates decreased drastically immediately below the first centimetre, being 6to 11-fold lower than in the superficial layer (Fig. 3). In contrast, in the Malaga upwelling area, the oxygen uptake rates were usually more homogeneous within the $2 \mathrm{~cm}$ thick upper layer. Although only the upper part of 2-3 cm layer was under oxic conditions (Fig. 2), it significantly contributed to the total oxygen consumption flow (Fig. 3). In the upwelling area, the oxygen uptake rates in the sediment layer comprised between $1 \mathrm{~cm}$ and the oxic-anoxic interfaces were higher than those measured in the frontal zone. This difference explains the shallower oxygen penetration depth in the upwelling area, relative to that observed at the frontal stations (Fig. 3, Table 3). 


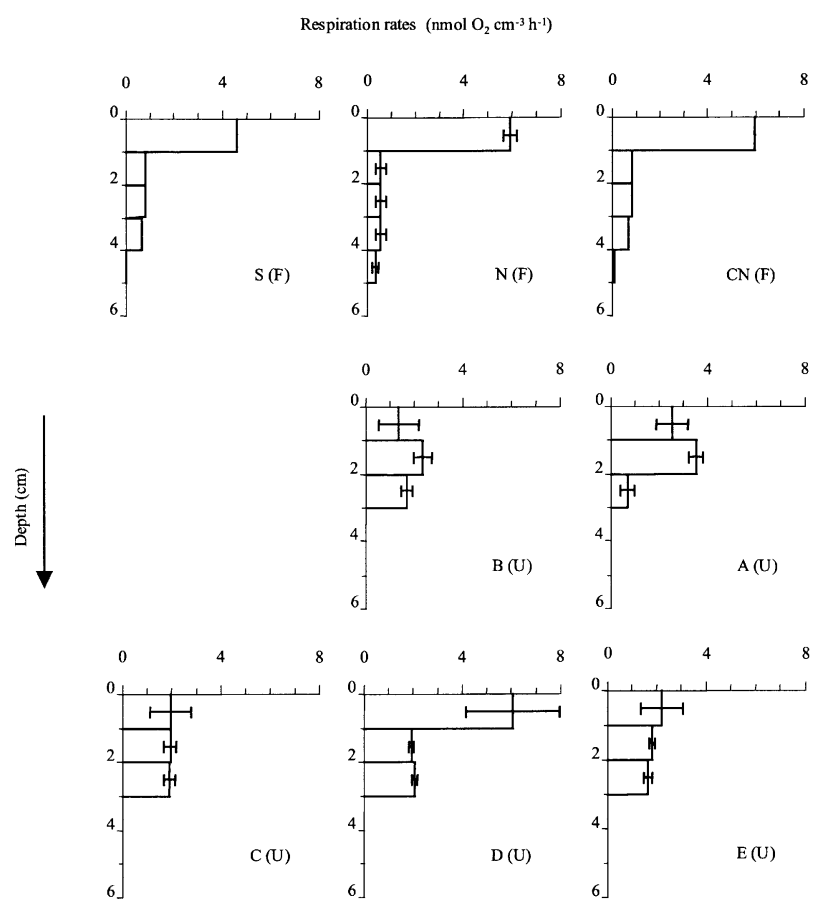

Fig. 3. Depth profiles of oxygen uptake rates in sediment cores collected in the Alboran Sea. Values obtained from replicate profiles $(n=4)$ were averaged for each $1 \mathrm{~cm}$ thick sediment layer; bars indicate SEM. Stations are listed in Table 1; (F): frontal area; (U): upwelling area.

\subsection{Distribution of microbial populations and microbial activity at the water-sediment boundary layer in the Alboran Sea}

Microbial density and potential rates for glutamate utilisation and ectoproteolysis in near bottom waters (NBW) are shown in Table 4. Microbial density and potential mineralisation rates decreased as sampling depth increased as usually observed for NBW microbial populations. However, ectoproteolysis activity was higher in the frontal zone than in the upwelling area (on average by a factor five) though occurring in shallower water (average depths: 2200 vs. $980 \mathrm{~m}$ ). Moreover, microbial density and glutamate uptake rates were lower in the frontal zone. Microbial densities in the NBW samples collected from stations $\mathrm{N}$ and $\mathrm{S}$ showed little difference $\left(0.98\right.$ and $1.31 \times 10^{4}$ cells ml ${ }^{-1}$, respectively) and potential glutamate uptake rates appear to be identical (451 $\left.\mathrm{pM} \mathrm{C} \mathrm{h}^{-1}\right)$.

Despite these homologies, the measured metabolic activity was different in the benthic waters at these two frontal stations. The hydrolysis rate was 4 -fold higher at station $\mathrm{N}$ than at station $\mathrm{S}$. This pattern is surprising, as sediment traps located $30 \mathrm{~m}$ above the sea floor showed that the particle flux at station $\mathrm{S}$ was more than twice that at Station N (663.3 and $306.3 \mathrm{mg} \mathrm{m}^{2} \mathrm{~d}^{-1}$, respectively). One would therefore expect a higher particle flux in the bottom waters at station $S$ (Table 5) to induce an enhancement in the High molecular weight (HMW) polymer hydrolysis rate.

There was no correlation between microbial density in the topmost sediment layer with water depth (Fig. 4). This has

Table 4

Bacterial densities, and potential rates for ${ }^{14} \mathrm{C}$-glutamate utilisation and ectoproteolysis ( \pm S.D.) in the near-bottom waters. F: frontal area; U: upwelling area

\begin{tabular}{|c|c|c|c|c|c|c|}
\hline S & Area & $\begin{array}{l}\text { Bacteria } \\
10^{4} \mathrm{ml}^{-1}\end{array}$ & Incorporation & $\begin{array}{l}{ }^{14} \mathrm{C} \text {-glutamate } \\
\text { Respiration } \\
\text { pM C h }{ }^{-1}\end{array}$ & Uptake & $\begin{array}{l}\text { MCA-Leu } \\
\text { Proteolysis } \\
\mathrm{nM} \mathrm{h}^{-1}\end{array}$ \\
\hline $\mathrm{S}$ & $\mathrm{F}$ & 0.98 & $318 \pm 85$ & $135 \pm 14$ & $452 \pm 74$ & $1.5 \pm 0.2$ \\
\hline $\mathrm{N}$ & $\mathrm{F}$ & 1.31 & $301 \pm 17$ & $150 \pm 11$ & $451 \pm 16$ & $6.1 \pm 1.1$ \\
\hline Average \pm SD & & $1.15 \pm 0.23$ & $310 \pm 12$ & $143 \pm 11$ & $450 \pm 2.6$ & $3.8 \pm 3.2$ \\
\hline B & $\mathrm{U}$ & 0.58 & $758 \pm 44$ & $387 \pm 19$ & $1146 \pm 60$ & $1.5 \pm 0.3$ \\
\hline A & $\mathrm{U}$ & 1.35 & $1067 \pm 65$ & $487 \pm 42$ & $1536 \pm 60$ & $0.7 \pm 0.2$ \\
\hline $\mathrm{C}$ & $\mathrm{U}$ & 2.28 & $291 \pm 52$ & $154 \pm 22$ & $445 \pm 72$ & $0.4 \pm 0.03$ \\
\hline D & $\mathrm{U}$ & 2.53 & $681 \pm 25$ & $677 \pm 176$ & $1359 \pm 111$ & $0.7 \pm 0.09$ \\
\hline E & $\mathrm{U}$ & 7.22 & $173 \pm 14$ & $234 \pm 38$ & $407 \pm 48$ & $0.6 \pm 0.04$ \\
\hline Average $\pm \mathrm{SD}$ & & $2.79 \pm 2.2$ & $594 \pm 363$ & $387 \pm 207$ & $955 \pm 503$ & $0.8 \pm 0.4$ \\
\hline
\end{tabular}

Table 5

Characteristics of the deposits in the Alboran Sea. Depth at which Eh $=0$, depths of the mixed layer, and mean sediment accumulation rates during the last ca. 100 years (from Masqué et al., accepted,)

\begin{tabular}{llllll}
\hline $\begin{array}{l}\text { Sampling station codes } \\
\text { UAB codes in cited ref. }\end{array}$ & This work & $\begin{array}{l}\text { Depth for Eh }=0 \\
(\mathrm{~mm})\end{array}$ & $\begin{array}{l}\text { Mixed layer } \\
(\mathrm{mm})\end{array}$ & $\begin{array}{l}\text { Particle flux } \\
\left(\mathrm{g} \mathrm{cm}^{-2} \text { year }^{-1}\right)\end{array}$ & $\begin{array}{l}\text { Sedimentation rate } \\
\left(\mathrm{mm} \mathrm{y}^{-1}\right)\end{array}$ \\
\hline T-6 & S & 75.0 & 30 & $0.063 \pm 0.006$ & $1.03 \pm 0.09$ \\
T-4 & N & 150 & 25 & $0.052 \pm 0.008$ & $0.50 \pm 0.08$ \\
T-5 & CN & 52.5 & 15 & $0.052 \pm 0.005$ & $0.65 \pm 0.06$ \\
ALB-1 & B & 57.5 & 40 & $0.079 \pm 0.005$ & $1.31 \pm 0.09$ \\
T-1 & A & 12.5 & 35 & $0.182 \pm 0.011$ & $2.7 \pm 0.2$ \\
ALB-2 & C & 22.5 & 55 & $0.058 \pm 0.002$ & $0.87 \pm 0.03$ \\
D & D & 77.5 & 90 & $0.101 \pm 0.010$ & $1.68 \pm 0.16$ \\
E & E & 45.0 & 35 & $0.043 \pm 0.002$ & $0.74 \pm 0.03$ \\
\hline
\end{tabular}


Bacteria $\left(x 10^{8}\right.$ cells $\left.\mathrm{ml}^{-1}\right)$
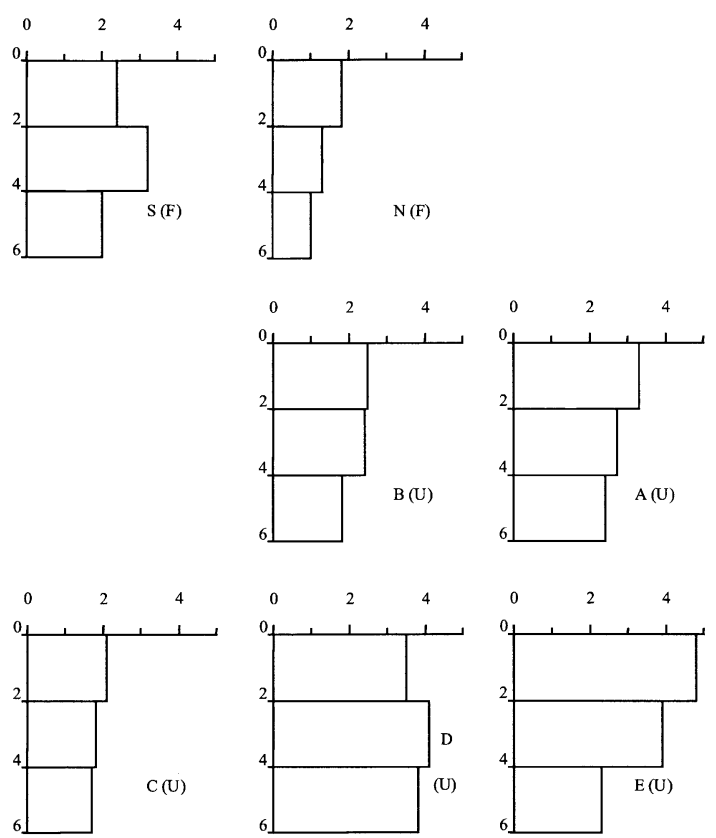

Fig. 4. Depth profiles of bacterial densities (direct counts $\times 10^{8}$ cells ml $\mathrm{m}^{-1}$ ) in sediment cores collected in the Alboran Sea. Stations are listed in Table 1; (F): frontal area; (U): upwelling area.

been previously observed (Danovaro et al., 1993; Boetius et al., 1996; Tholosan and Bianchi, 1998). The mean rates for glutamate mineralisation through the $6 \mathrm{~cm}$ sediment layer did not show a significant difference, despite the different depths of the two zones, values being $2120 \pm 131$ in the frontal zone and $2653 \pm 1636 \mathrm{pmol} \mathrm{C} \mathrm{cm}^{-2} \mathrm{~h}^{-1}$ in the upwelling area (Fig. 5). However, the hydrolysis rate differed greatly, being $154 \pm 68 \mathrm{nmol} \mathrm{MCA} \mathrm{cm}{ }^{-2} \mathrm{~h}^{-1}$ in the shallower upwelling area, and $1196 \pm 43 \mathrm{nmol} \mathrm{MCA} \mathrm{cm} \mathrm{M} \mathrm{h}^{-1}$ in the deeper frontal zone (Fig. 6). As previously observed (Tholosan and Bianchi, 1998), there was no straightforward coupling of microbial density and metabolic activity in the surface sediment layer, to those found in the corresponding overlaying benthic water.

\section{Discussion}

\subsection{Metabolic activity and oxygen profiles through the sediment depth}

The average diffusive oxygen uptake rate by the sediments was $1.7 \mathrm{mmol} \mathrm{O}_{2} \mathrm{~m}^{-2} \mathrm{~d}^{-1}$ for the entire data set. In the north-western Mediterranean, reported values range from below $1 \mathrm{mmol} \mathrm{O}_{2} \mathrm{~m}^{-2} \mathrm{~d}^{-1}$, at oligotrophic sites close to the Balearic Islands, and $4 \mathrm{mmol} \mathrm{d}^{-1} \mathrm{~m}^{-2}$ in the LacazeDuthiers Canyon. Here, diffusive oxygen uptake is strongly stimulated by macrofauna galleries (De Wit and Bouloubassi, 1998). Thus, the values we found in the Alboran Sea at the upwelling site and along the frontal zone are intermediate for the Western Mediterranean. This indicates

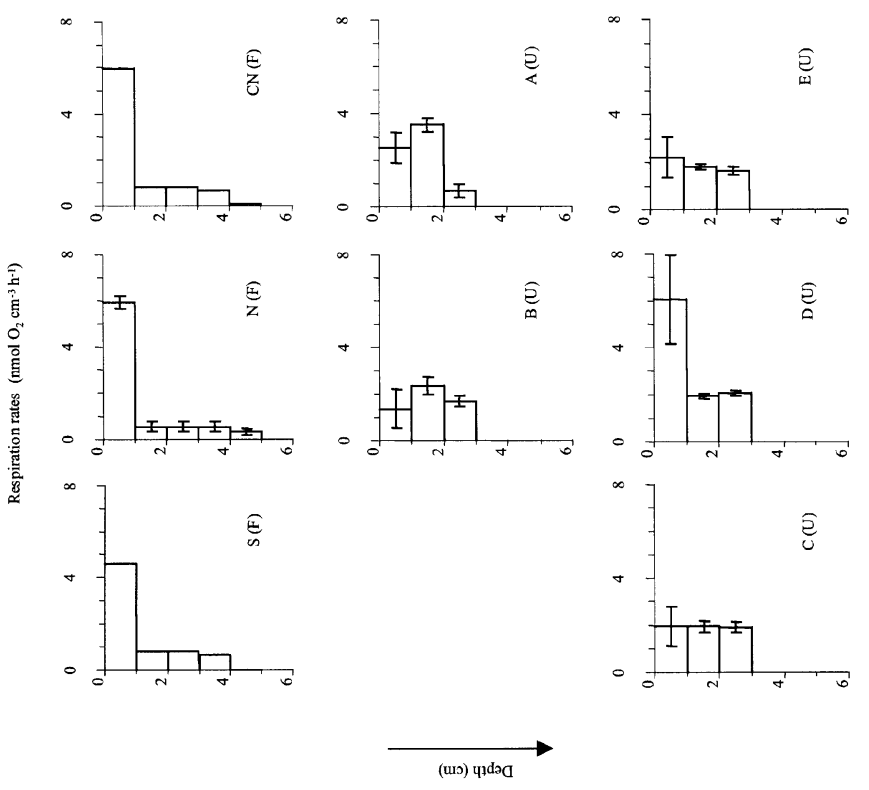

Fig. 5. Vertical profiles of ${ }^{14} \mathrm{C}$-glutamate potential remineralisation rates $\left(\mathrm{nM} \mathrm{C} \mathrm{h}^{-1}\right)$ in sediment cores collected in the Alboran Sea. Bars indicate S.D. Stations are listed in Table 1; (F): frontal area; (U): upwelling area.

a significant, albeit weak, stimulation of benthic metabolism during the study period (April) in the Alboran Sea associated with upwelling and frontal processes.

Microbial density was maximal in the superficial layer of the sediment decreasing only slightly through the sediment depth. At $6 \mathrm{~cm}$, the average microbial density was as high as $74 \%$ of the value observed in the topmost layer. Thus, the decrease in microbial activity through the profile of Alboran Sea deposits was not as dramatic as those found in sedi-

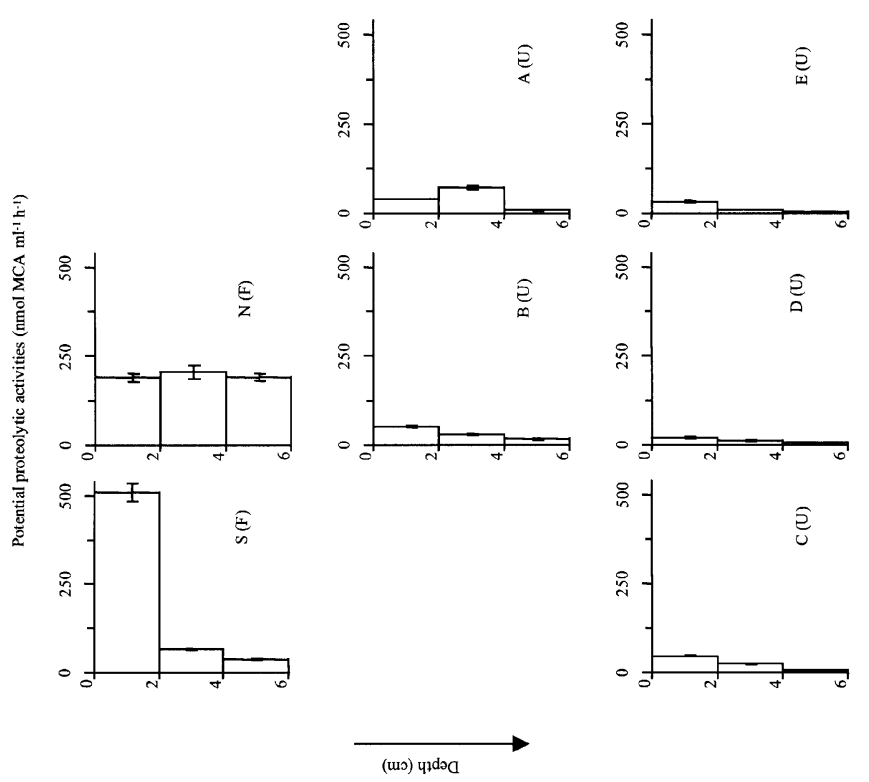

Fig. 6. Vertical profiles of potential proteolytic activities (nmol MCA $\mathrm{ml}^{-1} \mathrm{~h}^{-1}$ ) in sediment cores collected in the Alboran Sea. Bars indicate S.D. Stations are listed in Table 1; (F): frontal area; (U): upwelling area. 
ments analysed from the Gulf of Lions. Here, the surviving microbial population at $6 \mathrm{~cm}$ was only $45 \%$ of that found in the upper layer (Tholosan and Bianchi, 1998).

The mineralisation rates measured during the ${ }^{14} \mathrm{C}$ glutamate assays were also maximal in the superficial sediment layer (Fig. 5) decreasing, in the immediately subjacent layer, to be $33 \%$ (in the upwelling) and $27 \%$ (frontal zone) of their maximal values. The oxygen profiles (Fig. 2) and depth distribution of in situ aerobic respiration (Fig. 3) are in agreement with the microbial mineralisation profiles inferred from the ${ }^{14} \mathrm{C}$-glutamate assays (Fig. 5). This indicates that there are possible limiting factors in sedimentary microbial metabolism.

Along the frontal zone, oxygen penetrated to a depth of approximately $4 \mathrm{~cm}$ in the sediment, so at least in the top $4 \mathrm{~cm}$, this element can be excluded as the limiting factor for microbial metabolism. Through this layer, the main limiting factor is likely to be the scarcity of ready to use organic carbon compounds rather than low molecular oxygen concentrations. The sharp decrease in the oxygen uptake rate below $1 \mathrm{~cm}$, along with the drastic decrease in measured microbial respiration rate, but without a decrease in microbial density, indicates that carbon limitation becomes more severe below $1 \mathrm{~cm}$. In this frontal zone, it is only at depths below $4 \mathrm{~cm}$ that a shortage of molecular oxygen limits the metabolic activity of the aerobic bacteria. This favours the development of anaerobic prokaryotes, which are then able to use terminal electron acceptors rather than molecular oxygen.

In the Malaga upwelling area, oxygen penetrates the sediment layer to depths of between 2.2 and $2.9 \mathrm{~cm}$, indicating a possible oxygen limitation and co-occurrence of aerobic and anaerobic metabolism at a depth of $2 \mathrm{~cm}$ (Fig. 2). Such a shift from aerobic to anaerobic metabolism tends to reduce the mineralisation efficiency of microbial populations. In these sediments, oxygen uptake rates were more homogeneous throughout the top $2 \mathrm{~cm}$, indicating a similar degree of carbon limitation within this layer. Hence, below a depth of $1 \mathrm{~cm}$, oxygen uptake rates were higher when compared to the frontal zone (Fig. 3); this is likely to be responsible for the lower oxygen penetration depth in the upwelling area. This illustrates that the oxygen penetration depth in the sediment layer is influenced both by the oxygen concentration in the overlying water, by global respiration processes in the sediment, and by the depth distribution of the respiration rates. It is likely that both carbon limitation (through the 1-4 cm layer in the frontal zone), and oxygen depletion (below $2-4 \mathrm{~cm}$ in the upwelling and frontal zones, respectively), concomitantly contribute to the observed slow down of potential mineralisation rates.

Through the $6 \mathrm{~cm}$ sediment layer, the potential respiration rate (i.e. the energy yielding processes) decreases more drastically than the biopolymer hydrolysis rate. Within the 4-6 cm sediment layer, for both study areas, the glutamate mineralisation rates are $12-13 \%$ of the maximal values, which we observed in the topmost layer, whilst in the case of the hydrolysis processes, the remaining rates are $24 \%$ and
$33 \%$ of the maximal rates for the upwelling and the frontal zones, respectively.

This discrepancy in the pattern of the two metabolic steps, which intervene in the biodegradation process during the early phase of burial is probably due to the rapid removal of ready to use compounds (RUC) by heterotrophic bacteria within the topmost deposits. Hence, below the sediment surface, microbial metabolism depends mainly on the ability to use high-molecular weight organic compounds, which requires the persistence of polymer hydrolysis processes during the burial period.

\subsection{Comparison of benthic microbial activity in frontal and upwelling conditions}

In the benthic waters of the upwelling area, the glutamate mineralisation rates are enhanced 3-fold relative to their counterparts in the frontal zone (Table 4). In the superficial sediments, the potential mineralisation rates are $913 \mathrm{nMol} \mathrm{h}^{-1}$ in the upwelling area, and $762 \mathrm{nMol} \mathrm{h}^{-1}$ in the frontal zone. These rates are clearly higher than those described in other parts of the NW Mediterranean $\left(173 \pm 73 \mathrm{nMol} \mathrm{h}^{-1}\right.$, mean \pm S.D., $n=9$; (Tholosan and Bianchi, 1998)), or in the oligotrophic South Aegean Sea (174 $\pm 145 \mathrm{nMol} \mathrm{h}^{-1} ; n=9$, (Bianchi et al., 2000).

Enhancement of the potential mineralisation activities in the upwelling and frontal zones is consistent with the description of much higher primary production $\left(20.2 \mathrm{mmol} \mathrm{C} \mathrm{m}^{-2} \mathrm{~d}^{-1}\right)$ in the frontal zone, than in the Mediterranean waters a few miles to the north (9.8 $\mathrm{mmol} \mathrm{C} \mathrm{m}^{-2} \mathrm{~d}^{-1}$ ) (Sempéré et al., 2000). Similarly, particularly high chlorophyll concentrations determined by direct measurements (Minas et al., 1991) and satellite colour imagery (Ruiz et al., 2001) showed enhanced primary production in the upwelling area.

Ectoenzymatic hydrolysis of polypeptides follows the opposite trend to that observed for glutamate mineralisation processes. In the NBW, the average potential proteolysis rate is 5-fold higher in the frontal zone than in the upwelling area. In the sediments, the proteolysis rate is 9-fold higher in the frontal zone $\left(349 \pm 226\right.$ vs. $\left.38 \pm 12 \mu \mathrm{Mol} \mathrm{MCA} \mathrm{h}^{-1}\right)$. Comparison with other data shows that in the upwelling area, the proteolysis rate is lower than that measured in other sediments from the Western Mediterranean $(136 \pm 118 \mu \mathrm{Mol} \mathrm{MCA})$, or from the South Aegean Sea $\left(280 \pm 127 \mu \mathrm{Mol} \mathrm{MCA} \mathrm{h}^{-1}\right.$, op. cited). Conversely, in the frontal zone, the potential hydrolysis rates are higher than those reported in these Mediterranean areas. This confirms previous descriptions of elevated ectoenzymatic activities in surficial sediments in other frontal zones. (Griffiths et al., 1983) related the high microbial activities that they measured in surficial sediments of the Southeastern Bering Sea to the influence of frontal conditions on primary productivity and sedimentation processes. (Talbot and Bianchi, 1997) described the same pattern in the Frontal zone of the Antarctic Ocean. Our data are also consistent with the strong correlation between pigment concentration and ectoenzymatic ac- 
tivities observed by (Boetius et al., 1996) in sediments from the Eastern Mediterranean Trenches, where hydrodynamic conditions lead to the deposition of relatively fresh detritus.

The high proteolysis rates we measured could be due simply to an increase in cell abundance. Calculations of cell specific activities normalise the efficiency of microbial populations, independent of any environmental conditions, which may aeffect the population density. Bacterial cells in the NBW of the frontal zone are less efficient in glutamate mineralisation processes than those in the upwelling area, the specific rates being $12.6 \pm 1.6$ and $27.9 \pm 25.1$ amol $\mathrm{CO}_{2}$ produced cell ${ }^{-1} \mathrm{~h}^{-1}$, respectively. In the surficial sediment, specific respiration rates in the frontal zone are higher than in the upwelling area $(3.6 \pm 1.8 \mathrm{vs}$. $2.7 \pm 1.4$ amol $\mathrm{CO}_{2}$ produced cell ${ }^{-1} \mathrm{~h}^{-1}$ ). With reference to polypeptide hydrolysis, a more specialised functional process, specific activity is clearly higher in the frontal zone, both in the NBW $(309 \pm 220$ and $72 \pm 10$ amol MCA cell ${ }^{-1} \mathrm{~h}^{-1}$, respectively), and in the surficial sediment. In this latter case, enhancement relative to the upwelling area is more than one order of magnitude $\left(1585 \pm 757\right.$ vs. $135 \pm 75$ amol MCA hydrolysed cell $\left.{ }^{-1} \mathrm{~h}^{-1}\right)$.

Relative to the peptidase specific activity measured over the same seasonal period in the South Aegean Sea $\left(363 \pm 202\right.$ amol MCA hydrolysed cell ${ }^{-1} \mathrm{~h}^{-1}$, Bianchi et al., 2000), ectoenzymatic abilities appear to be elevated in the frontal zone, but lower in the upwelling area. Such a difference shows that: (1) benthic microbial populations of the upwelling area have enough RUC in the organic inputs to support metabolism without having to draw on carbon and energy from the polymer bulk via ectoenzymatic processes and (2) in the frontal zone, microbial populations are more efficient in proteolysis processes than those of the upwelling area.

The two metabolic processes we studied are concerned with the degradation of nitrogenous organic compounds, the ectoenzymatic hydrolysis of polypeptides being the preliminary step to amino acid mineralisation. The ratio "hydrolysis rate/mineralisation rate" reports a theoretical estimation of the relative efficiency of these two processes. From the mean potential rates measured, microbial populations from the upwelling NBW and sediments should, theoretically, have to hydrolyse 2 and 58 pmol of polypeptides, respectively, in order to mineralise 1 pmol of carbon from an LMW organic compound. Meanwhile, to mineralise the same quantity of carbon, their counterparts in the frontal zone would need to hydrolyse 10-fold more HMW compounds, i.e. up to 27 and 564 pmol of polypeptides, respectively. This result suggests a clear uncoupling between polypeptide hydrolysis and amino acid mineralisation processes in the frontal zone.

Unanue et al., (1998) demonstrated that during the bacterial decomposition of phytoplankton-derived particles, aminopeptidase activity and the uptake of hydrolysate may be uncoupled when particles are largely degraded. Indeed, the uncoupling we observed could be due to the longer residence time of particles in the deeper frontal water column, than in the upwelling area. Yet, in the experiments described by Unanue et al. (1998), uncoupling is due to a slow down in uptake rates. Conversely, in the benthic area of the Alboran Sea, uncoupling is more likely to be due to an overproduction of ectoenzymes by the frontal populations. This is because their cell specific activity is one order of magnitude higher than in the upwelling area (1 $585 \pm 757$ vs. $135 \pm 75$ amol MCA cell ${ }^{-1} \mathrm{~h}^{-1}$ ).

The difficulty in obtaining multiple samples from each deep-sea station prevents us from establishing our comparison of microbial activity through the two areas on a statistical basis. Nevertheless, enhancement of proteolysis activity in the frontal zone appears similar both in the NBW and in the sediments. Indeed, this functional discrepancy between the benthic microbial populations of the two areas probably originates from the difference in the quality of the nutrient inputs.

In the upwelling area, hydrological conditions favour high algal productivity (Minas et al., 1991), and sediment trap data show that particulate inputs in the benthic zone are more abundant here than in the frontal zone (Table 5). In the upwelling area, being shallower $(\sim 1000 \mathrm{~m})$ than the frontal zone $(\sim 2200 \mathrm{~m})$, the residence time of sinking particles through the water column is shorter, which prevents the complete exhaustion of RUC by pelagic bacteria. Indeed, inhibition of enzymatic hydrolysis processes by RUC availability has been demonstrated (Chrost, 1991; Boetius and Lochte, 1994). Despite a higher particle flux in the upwelling area, RUC availability initiates a slowing down of biopolymer hydrolysis processes, relative to the high activities measured in the frontal zone. High peptidase rates may be considered as evidence of oligotrophic conditions. This is because peptidase activity has been described as being negatively related to nutrient concentration (Hoppe, 1983), inhibited by substrate addition (Boetius and Lochte, 1994), and negatively correlated to depth (Tamburini et al., 2002).

Indeed, to find similar hydrolysis rates in highly oligotrophic areas, like the Eastern Mediterranean Sea (Bianchi et al., submitted), and in areas of high-productivity, i.e. the Malaga Frontal zone is surprising. (Vetter and Deming, 1994) disputed such versatile relationships between protease activity and nutrients. They hypothesised that this adaptability could be associated to the time variability of nitrogen availability. Similarly, (Boetius and Lochte, 1994) suggested that the hydrolysis rate in deep-sea sediments depend more on the state, or quality, of the nutrient inputs rather than on their quantity. Our data support this hypothesis.

In the frontal zone, the accumulating TOC in the water column, consisting of semi-labile material, turning over on a seasonal time scale, accounts for $40 \%$ of the TOC bulk (Table $2)$. This percentage is higher than that calculated in the upwelling area (31\%). Our results suggest that in the frontal zone, more DOC escapes mineralisation, and so accumulates in the water column. Such observations agree with the paradigm indicating a shift from a microbial dominated food 
web exporting DOC in oligotrophic or semi-oligotrophic areas, to systems dominated by classical food chains exporting carbon via the sinking particle flow in eutrophic areas (Thingstad et al., 1997). Before being re-mineralised such particulate material must be hydrolysed by ectoenzyme producing microbial populations, hence the enhancement of the proteolysis rates and cell specific activities, which we observed in the NBW and sediments in the frontal zone.

\section{Acknowledgements}

This work was supported by the European Commission's Marine Science and Technology (Mast) Program, under MTP-Mater project contract MAS3-CT96-0051, and the Institut National des Sciences de l'Univers. Authors thank officers and crew of RV Hespérides and UGBO technicians for assistance at sea, and Tracy Bentley for improving the English language.

\section{References}

Alldredge, A.L., Silver, M.W., 1988. Characteristics, dynamics and significance of marine snow. Prog. Oceanogr 20, 41-82.

Bianchi, A., Tholosan, O., Garcin, J., Polychronaki, T., Tselepides, A., Buscail, R., Duineveld, G., 2000. Microbial activities at the benthic boundary layer in the Aegean Sea. Prog. Oceanogr (submitted for publication).

Boetius, A., Lochte, K., 1994. Regulation of microbial enzymatic degradation of organic matter in deep-sea sediments. Mar. Ecol. Prog. Ser 104, 299-307.

Boetius, A., Scheibe, S., Tselipides, A., Thiel, H., 1996. Microbial biomass and activities in deep-sea sediments of the Eastern Mediterranean: trenches are benthic hotspots. Deep-Sea Res. I 43, 1439-1460.

Chrost, R.J., 1991. Environmental control of the synthesis and activity of aquatic microbial ectoenzymes. In: Chrost, R.J. (Ed.), Microbial Enzymes in Aquatic Environments. Springer-Verlag, New York, pp. 29-59.

Dafner, E., Sempéré, R., Gonzales, N., Gomez, F., Goutx, M., 1999. Cross slope variations of dissolved organic carbon in the Gulf of Cadiz, NE Atlantic Ocean (February 1998). Mar. Ecol. Prog. Ser 189, 301-306.

Danovaro, R., Fabiano, M., Croce, N.D., 1993. Labile organic matter and microbial biomasses in deep-sea sediments (Eastern Mediterranean Sea). Deep-Sea Res 40, 953-965.

De Wit, R., Bouloubassi, I., 1998. Oxygen penetration depth and aerobic microbial respiration in sediments of the Western Mediterranean. Third MTP-II Workshop on the Variability of the Mediterranean Sea. Rhodos, (Greece), pp. 207.

De Wit, R., Relexans, J.C., Bouvier, T., Moriarty, D., 1997. Microbial respiration and diffusive oxygen uptake of deep-sea sediments in the Southern Ocean (ANTARES-I cruise). Deep-Sea Res II 44, 1053-1068.

García-Lafuente, J., Cano, N., Vargas, M., Rubin, J.P., HernandezGuerra, A., 1998. Evolution of the Alboran Sea hydrographic structures during July 1993. Deep-Sea Res. I 45, 39-65.

Griffiths, R.P., Caldwell, B.A., Broich, W.A., Morita, R.Y., 1983. Microbial processes relating to carbon cycling in Southeastern Bering Sea sediments. Mar. Ecol. Prog. Ser 10, 265-275.

Grout, H., Sempéré, R., Calafat, A., Prieur, L., Canals, M., 2001. Morphological and chemical variability of colloids in the AlmeriaOran Front in the Eastern Alboran Sea (SW Mediterranean Sea): evidence by means of Analytical Electron Microscopy. Limnol. Oceanogr 46, 1347-1357.
Hoppe, H.G., 1983. Significance of exoenzymatic activities in the ecology of brackish water: measurement by means of methylumbelliferylsubstrates. Mar. Eco. Prog. Ser 11, 299-308.

Hoppe, H.G., Ullrich, S., 1999. Profiles of ectoenzymes in the Indian Ocean: phenomena of phosphatase activity in the mesopelagic zone. Aquat. Microb. Ecol 19, 139-148.

Masqué, P., Fabrés, J., Canals, M., Sanchez-Cabeza, J.A., SanchezVidal, A., Cacho, I., Calafat, A., Bruach, J., 00. Accumulation rates of major contituents of hemipelagic sediments in the deep Alboran Sea: a centennial perspective of sedimentary dynamics. Mar. Geology.

Minas, H.J., Coste, B., Le Corre, P., Minas, M., Raimbault, P., 1991. Biological and geochemical signatures associated with the water circulation through the Strait of Gibraltar and the Western Alboran Sea. J. Geophys. Res 96, 8755-8771.

Packard, T.T., Minas, H.J., Coste, B., Martinez, R., Bonin, M.C., Gostan, J., Garfield, P., Christensen, J., Dortch, Q., Minas, M., CopinMontégut, G., Copin-Montégut, C., 1988. Formation of the Alboran oxygen minimum zone. Deep-Sea Res Part A 35, 1111-1118.

Parrilla, G., Kinder, Th., Preller, R., 1986. Deep and intermediate Mediterranean water in the western Alboran Sea. Deep-Sea Res. Part A 33, $55-86$.

Poremba, K., 1994. Simulated degradation of phytodetritus in deep-sea sediments of the NE Atlantic $\left(47^{\circ} \mathrm{N}, 19 \mathrm{~W}\right)$. Mar. Ecol. Prog. Ser 105, 291-299.

Porter, K.G., Feig, Y.S., 1980. The use of DAPI for identifying and counting aquatic microflora. Limnol. Oceanogr 25, 943-948.

Prieur, L., Copin-Montégut, C., Claustre, H., 1993. Biophysical aspects of "Almofront-1", an intensive study of geostrophic frontal jet. Ann. Inst. Océanogr. Paris 69, 71-86.

Ruiz, J., Echevarria, F., Font, J., Ruiz, S., Garcia, E., Blanco, J.M., Jimenez-Gomez, F., Prieto, L., Gonzalez-Alaminos, A., Garcia, C.M.U., 2001. Surface distribution of chlorophyll, particles and gelbstoff in the Atlantic jet of the Alboran Sea: from submesoscale to subinertial scales of variability. J. Mar. Syst 29 (1-4), 277-292.

Sempéré, S., Dafner, E., Magen, C., Allegre, S., Van Wambeke, F., Lefèvre, D., Bianchi, M., Prieur, L., 2000. Total organic carbon and cycling across a geostrophic front in Mediterranean Sea implications for the western carbon cycle (submitted for publication).

Talbot, V., Bianchi, M., 1997. Bacterial proteolytic activity in sediments of the Subantarctic Indian Ocean Sector. Deep-Sea Res. II 44, 1069-1084.

Tamburini, C., Garcin, J., Ragot, M., Bianchi, A., 2002. Biopolymer hydrolysis and bacterial production under ambient hydrostatic pressure through a $2000 \mathrm{~m}$ water column in the NW Mediterranean. Deep-Sea Res. II 49, 2109-2123.

Thingstad, T.F., Hagström, A., Rassoulzadegan, F., 1997. Accumulation of degradable DOC in surface waters: is it caused by a malfunctioning microbial loop? Limnol. Oceanogr 42, 398-404.

Tholosan, O., Bianchi, A., 1998. Bacterial distribution and activity at the water-sediment boundary layer on NW Mediterranean continental margin. Mar. Ecol. Prog. Ser 168, 273-283.

Turley, C.M., Mackie, P.J., 1994. Biogeochemical significance of attached and free-living bacteria and the flux of particles in the NE Atlantic Ocean. Mar. Ecol. Prog. Ser 115, 191-203.

Unanue, M., Azua, I., Arrieta, J.M., Labirua-Iturburu, A., Egea, L., Iriberri, J., 1998. Bacterial colonization and ectoenzymaic activity in phytoplankton-derived model particles: cleavage of peptides uptake of amino acids. Microbiol. Ecol 35, 136-146.

Vetter, Y.A., Deming, J.W., 1994. Extracellular enzyme activity in the Artic Northeast water polynya. Mar. Ecol. Prog. Ser 114, 23-34. 